\title{
Analisis Faktor yang Mempengaruhi Lama Waktu Pembayaran Angsuran Pertama Program ZIS Produktif Baitul Mal Aceh
}

\author{
SAmsul ANWAR, Afriyani, Desfira Ahya, Nurhidayati, NOVIRA IsWANI, ReZA \\ ARISKA, RUDI WAHYUDI \\ Jurusan Statistika, Fakultas MIPA, Universitas Syiah Kuala Banda Aceh, \\ Jl. T. Nyak Arief. Kopelma Darussalam, Banda Aceh 23111 \\ Email: samsul.anwar@unsyiah.ac.id
}

\begin{abstract}
ABSTRAK
Data lama waktu pembayaran angsuran pertama dana bantuan modal usaha program ZIS Produktif Baitul Mal Provinsi Aceh dapat dianalisa dengan menggunakan metode analisis survival. Penelitian ini menggunakan data mustahik (penerima zakat) yang mendapatkan bantuan modal usaha melalui program ZIS Produktif untuk kategori lancar dengan jumlah sampel sebanyak 50 kasus. Data lama waktu pembayaran angsuran pertama dikategorikan tersensor apabila waktu pembayaran angsuran tersebut lebih lama dari 2 bulan sejak tanggal bantuan modal usaha tersebut diterima. Analisa data dalam penelitian ini menggunakan model Cox Proportional Hazard (Cox PH). Model tersebut digunakan untuk mengidentifikasi variabel penjelas yang berpengaruh terhadap lama waktu pembayaran angsuran pertama dana bantuan modal usaha program ZIS Produktif Baitul Mal Provinsi Aceh. Selain itu, model Cox PH juga bisa digunakan untuk menentukan nilai hazard rasio antar kategori dalam variabel penjelasnya. Berdasarkan hasil penelitian, diketahui bahwa terdapat 4 variabel yang mempengaruhi lama waktu mustahik dalam membayar angsuran pertama mereka. Keempat variabel tersebut adalah pekerjaan, kelompok usia, jumlah pinjaman, dan tempat tinggal mustahik.
\end{abstract}

Kata Kunci: Cox proportional hazard, lancar, mustahik, pembayaran angsuran pertama, ZIS produktif.

\section{PENDAHULUAN}

Kewajiban membayar zakat merupakan salah satu dari lima Rukun Islam, tepatnya rukun yang ketiga (Jim, 2017). Selain itu, perintah membayar zakat juga dijelaskan dalam Al-Qur'an Surah Al-Baqarah [2]: 43, 83, 110, 177 dan 277; An-Nisa'[4]: 77 dan 162; Al-Ma'idah [5]: 12 dan 55; At-Taubah [9]: 5, 11, 18 dan 71; Al-'Anbya' [21]: 73; Al-Haj [22]: 41 dan 78; An-Nur [24]: 37 dan 56; An-Naml [27]: 3; Luqman [31]: 4; Al-‘Azhab [33]: 33, Al-Mujadila [58]: 13; A1Muzzammil [73]: 20; serta Al-Bayyinah [98]: 5 (Al-quran al-hadi, 2017). Berdasarkan dalil tersebut, membayar zakat merupakan suatu kewajiban yang harus dilaksanakan oleh seluruh umat Islam. Provinsi Aceh merupakan provinsi dengan persentase penduduk beragama Islam terbanyak di Indonesia yaitu sebesar 98,93\% (BPS Aceh, 2014). Sehingga Provinsi Aceh memiliki potensi zakat yang bernilai sangat besar. Oleh karena itu, diperlukan suatu lembaga khusus yang mampu mengelola zakat tersebut secara profesional, transparan, kredibel dan amanah. Lembaga tersebut adalah Baitul Mal Aceh yang ditetapkan melalui Qanun Aceh Nomor 10/2007 pada bulan Januari 2008.

Baitul Mal merupakan lembaga pemerintah daerah non struktural, dan bersifat independent dalam melaksanakan tugasnya. Dana zakat yang dikelola oleh Baitul Mal akan disalurkan kepada para mustahik (peneriman zakat) yang berhak. Selain itu, Baitul Mal juga memiliki beberapa program unggulan, diantaranya: program dalam bidang pendidikan, sosial, pemberdayaan ekonomi, serta dakwah dan syiar Islam. Salah satu program unggulan dalam bidang pemberdayaan ekonomi adalah pemberian pinjaman modal usaha kepada mustahik yang memiliki wirausaha kecil dengan tujuan membantu usaha tersebut agar dapat terus berkembang, produktif dan mandiri. Program pemberdayaan ekonomi ini disebut dengan program ZIS Produktif Baitul Mal yang pertama kali dijalankan pada tahun 2006. Selama kurun waktu tahun 2006 sampai dengan tahun 2015, tercatat sebanyak 2.083 mustahik 
kelompok usaha kecil di Kota Banda Aceh dan Kabupaten Aceh Besar yang telah dibantu melalui program ZIS Produktif ini (Baitul Mal Aceh, 2015).

Pembiayaan modal usaha yang ditujukan kepada mustahik pelaku usaha mikro ini menganut prinsip pembiayaan tanpa bunga dan bersifat revolving fund atau dana bergulir (Baitul Mal Aceh, 2015). Dengan demikian, Baitul Mal menyalurkan bantuan modal usaha tanpa mengambil profit atau keuntungan. Mustahik membayar kembali bantuan modal usaha tersebut dengan jumlah yang sama. Besarnya bantuan modal usaha yang dapat diperoleh mustahik sangat bervariasi tergantung pada kebutuhan dan tingkat kepatuhan mustahik dalam pengembalian modal usaha pada masa peminjaman sebelumnya. ZIS Produktif disalurkan dalam periode pinjaman satu tahun sejak dana bantuan modal usaha tersebut disalurkan kepada mustahik.

Dalam hal pengembalian bantuan modal usaha tersebut, mustahik diberikan keringanan untuk dapat mengembalikannya dengan cara mengangsur pada setiap bulan saat jatuh tempo. Sehingga diharapkan mustahik tidak akan mengalami kesulitan dalam mengembalikan pinjaman modal usaha tersebut. Meskipun demikian, masih banyak mustahik yang tidak membayar angsuran tersebut tepat waktu. Berkaitan dengan ketepatan waktu pembayaran angsuran tersebut, mustahik dapat dikategorikan ke dalam 4 kelompok, yaitu kategori lancar, diragukan, ragu-ragu dan macet. Mustahik dikategorikan lancar apabila keterlambatan pembayaran angsuran yang dilakukan kurang dari 3 kali, kategori diragukan untuk keterlambatan antara 4 - 6 kali, kategori ragu-ragu untuk keterlambatan antara 7 - 24 kali, dan kategori macet apabila keterlambatan pembayaran lebih dari 24 kali.

Mustahik dengan kategori lancar merupakan kelompok yang paling menarik untuk dipelajari. Meskipun dikategorikan lancar, masih terdapat kemungkinan bagi seorang mustahik untuk dapat terlambat membayarkan angsurannya paling banyak selama $3 \mathrm{kali}$. Ada beberapa faktor eksternal dan internal yang diduga menyebabkan keterlambatan pembayaran angsuran tersebut. Pembayaran angsuran pertama sejak tanggal dicairkannya bantuan modal usaha kepada masing-masing mustahik merupakan peristiwa yang menarik untuk dikaji. Keterlambatan pembayaran angsuran pertama dapat mengindikasikan tingkat ketaatan mustahik dalam membayar angsuran tahap berikutnya. Berdasarkan latar belakang tersebut, dapat dirumuskan sebuah permasalahan yaitu faktor-faktor apa saja yang mempengaruhi mustahik dalam membayarkan angsuran pertama dana bantuan modal usaha program ZIS Produktif Baitul Mal Aceh.

\section{KAJIAN LITERATUR}

\section{Analisis Survival}

Menurut Kleinbaum (2005), analisis survival adalah suatu metode statistik yang digunakan untuk menganalisis data dengan variabel respon yang diperhatikan berupa waktu sampai terjadinya suatu kejadian. Terdapat tiga tujuan utama dari analisis survival, yaitu melakukan estimasi dan interpretasi fungsi hazard dan fungsi survival, melakukan perbandingan antara fungsi hazard dan fungsi survival pada dua kelompok sampel atau lebih, dan mencari hubungan antara waktu survival dengan variabel penjelas yang diduga mempengaruhi waktu survival tersebut. Penelitian ini lebih menekankan pada tujuan yang ketiga, yaitu mengetahui hubungan antara waktu survival dengan variabel penjelas yang mempengaruhinya.

\section{Fungsi Hazard dalam Analisis Survival}

Masa hidup dari sebuah sampel atau unit adalah panjang interval waktu, $T$, dari waktu pertama kali sampel atau unit tersebut berfungsi atau hidup sampai dengan waktu pada saat sampel atau unit tersebut mengalami kegagalan fungsi atau mati. Variabel waktu $T$ tersebut didefinisikan sebagai sebuah random variabel karena lamanya masa hidup tersebut tidak bisa diprediksi secara tepat. Salah satu fungsi penting dalam analisis survival adalah fungsi hazard yang disimbolkan dengan $h(t)$. Menurut Zacks (1991), fungsi hazard menjelaskan laju kegagalan seketika dari sebuah unit yang telah memiliki masa hidup $t$ satuan waktu. Hazard rate atau instantaneous event rate dapat diestimasi melalui perbandingan (rasio) antara jumlah sampel kejadian yang diamati $(d)$ dengan total waktu survival, atau secara matematis dapat ditulis dengan persamaan: 
$\lambda=\frac{d}{f+F}$

dimana $f=\sum t_{i}$, dan $F=\sum T_{j}^{+}$. Komponen $t_{i}$ merupakan waktu survival dari $d$ buah sampel kejadian yang telah mengalami kegagalan fungsi (data tidak tersensor), sedangkan $T_{j}^{+}$ merupakan waktu survival dari $(n-d)$ buah sampel kejadian yang masih berfungsi (data tersensor) (Machin, 2006).

Fungsi hazard untuk sampel tertentu, $\lambda(t)$, merupakan produk dari fungsi hazard rata-rata, $\lambda_{0}(t)$, dengan sebuah fungsi yang dapat berubah terhadap waktu, $h(t)$. Secara matematis dapat ditulis dengan persamaan:

$\lambda(t)=h(t) \lambda_{0}(t)$.

Fungsi tersebut juga dapat ditulis sebagai perbandingan (rasio) dari fungsi hazard untuk sampel tertentu dengan fungsi hazard rata-rata. Fungsi tersebut kemudian disebut dengan fungsi hazard relatif, dan secara matematis dapat ditulis melalui persamaan:

$h(t)=\frac{\lambda(t)}{\lambda_{0}(t)}($ Machin, 2006).

\section{Model Cox Proportional Hazard (Cox PH)}

Model Cox Proportional Hazard (Cox $P H$ ) merupakan salah satu model statistik yang sering digunakan dalam analisa data survival. Model Cox $P H$ biasanya ditulis dalam bentuk formulasi bentuk hazard dalam persamaan matematis:

$$
h(t, \boldsymbol{X})=h_{0}(t) \exp \left(\sum_{i=1}^{p} \beta_{i} X_{i}\right) .
$$

Dimana matriks $\boldsymbol{X}=\left(X_{1}, X_{2}, \ldots, X_{p}\right)$, merupakan kumpulan variabel penjelas dari Cox $P H$ model. Variabel penjelas $X$ tersebut digunakan untuk melakukan prediksi nilai hazard individu pada saat waktu $t$. Model Cox $P H$ menjelaskan bahwa nilai hazard pada waktu $t$ merupakan produk dari dua buah komponen. Pertama, $h_{0}(t)$, yang disebut dengan fungsi baseline hazard, dan komponen kedua adalah fungsi eksponensial, exp, dari penjumlahan linear fungsi $\beta_{i} X_{i}$, untuk $p$ buah variabel penjelas $X$. Sebagai catatan, fungsi baseline hazard merupakan sebuah fungsi dari waktu $t$, tetapi tidak melibatkan variabel penjelas $X$. Disisi lain, ekpresi dari fungsi eksponensial melibatkan variable penjelas $X$, tetapi tidak dengan variabel waktu $t$. Sehingga variable penjelas $X$ disebut dengan time independent (Kleinbaum, 2011).

Hazard rasio didefenisikan sebagai perbandingan hazard dari dua buah kelompok. Pada umumnya antara kelompok dengan nilai hazard yang lebih besar (misalnya kelompok kontrol/placebo) dengan kelompok dengan nilai hazard yang lebih kecil (misalnya kelompok perlakuan/treatment). Hazard rasio tersebut secara matematis dapat ditulis sebagai:

$$
\widehat{H R}=\frac{\hat{h}\left(t, \boldsymbol{X}^{*}\right)}{\widehat{h}(t, \boldsymbol{X})} .
$$

dimana $\boldsymbol{X}^{*}=\left(X_{1}^{*}, X_{2}^{*}, \ldots, X_{p}^{*}\right)$, dan $\boldsymbol{X}=\left(X_{1}, X_{2}, \ldots, X_{p}\right)$. Dalam model Cox $P H$, nilai hazard rasio dapat diestimasi melalui persamaan:

$$
\widehat{H R}=\exp \left(\sum_{i=1}^{p} \widehat{\beta}_{l}\left(X_{i}^{*}-X_{i}\right) .\right.
$$

Nilai hazard rasio tersebut dapat dengan mudah dikalkulasikan setelah nilai koefisien $\widehat{\beta}_{l}$ diestimasi. Asumsi penting dari model Cox $P H$ adalah asumsi Proportional Hazard $(P H)$ yang menyatakan bahwa hazard rasio memiliki nilai yang konstan terhadap waktu. Dengan kata lain, hazard untuk seorang individu/sampel adalah proporsional terhadap hazard setiap individu/sampel lainnya, dan nilainya proporsional konstan serta independen terhadap waktu (Kleinbaum, 2011). Secara matematis hazard rasio tersebut dapat ditulis sebagai berikut:

$$
\frac{\hat{h}\left(t, \boldsymbol{X}^{*}\right)}{\hat{h}(t, \boldsymbol{X})}=\hat{\theta} .
$$

Pengujian asumsi $P H$ dapat dilakukan dengan menggunakan goodness of fit test yaitu statistik Chi-square. Nilai $p$-value dari statistik Chi-square yang tidak signifikan mengindiksikan bahwa asumsi $P H$ terpenuhi (Kleinbaum, 2011). 
Selain itu, dua uji statistik yang penting lainnya dalam model Cox PH adalah statistik Wald dan Likelihood Ratio (LR) test. Statistik Wald digunakan untuk menguji apakah koefisien dari model Cox $P H$ bernilai signifikan secara statistik. Statistik Wald, yang disimbolkan dengan $W$, didefenisikan sebagai berikut (Machin, 2006):

$$
W=\left(\frac{\hat{\beta}_{j}}{\operatorname{se}\left(\hat{\beta}_{j}\right)}\right)^{2} .
$$

Sedangkan $L R$ test digunakan untuk melakukan uji signifikansi dari komponen interaksi antar variabel dalam model Cox $P H$. LR test secara umum didefiniskan sebagai berikut:

$$
L R=-2 \ln L_{R}-2 \ln L_{F}
$$

dimana $R$ menandakan model yang direduksi dan $F$ menandakan model lengkap, dengan $\ln L$ adalah nilai Log likelihood dari model tersebut (Kleinbaum, 2011). Statistik Wald juga sering disebut dengan uji secara parsial, sedangkan LR test merupakan uji secara serentak dari model Cox $P H$.

\section{METODE PENELITIAN}

Penelitian ini dilakukan di Kantor Baitul Mal Provinsi Aceh yang beralamat di Jl. T. Nyak Arief Komplek Keistimewaan Aceh, Kota Banda Aceh. Program unggulan Baitul Mal Aceh yang dianalisa adalah program pemberdayaan ekonomi ZIS Produktif. Jumlah sampel yang digunakan untuk mustahik kategori lancar adalah sebanyak 50 orang. Adapun variabel penjelas yang digunakan dalam penelitian ini adalah lama waktu pembayaran angsuran pertama modal usaha program ZIS Produktif $(T)$, jenis kelamin mustahik $\left(\mathrm{X}_{1}\right)$, pekerjaan mustahik $\left(\mathrm{X}_{2}\right)$, usia mustahik $\left(\mathrm{X}_{3}\right)$, jumlah biaya yang dipinjam $\left(\mathrm{X}_{4}\right)$, penanggung jawab peminjaman apakah secara berkelompok ataupun secara individual (X5), dan kecamatan tempat domisili mustahik $\left(\mathrm{X}_{6}\right)$. Metode analisa statistik yang digunakan dalam penelitian ini adalah analisis survival model Cox $P H$. Tujuan penggunaan model ini adalah untuk mengetahui faktor-faktor yang mempengaruhi lamanya waktu pembayaran angsuran pertama program ZIS Produktif Baitul Mal Provinsi Aceh. Pengolahan data dengan analisis survival model Cox $P H$ menggunakan software $R$ versi 3.2.2.

Adapun langkah-langkah analisa dalam penelitian ini adalah sebagai berikut: (1) Membangun model Cox PH untuk basemodel dengan memasukan semua variabel penjelas dalam penelitian; (2) Seleksi variabel dilakukan dengan memilih variabel penjelas yang signifikan secara parsial dari basemodel pada tingkat signifikansi $a=0,1$; (3) Membangun model Cox $P H$ final dengan menggunakan variabel penjelas yang signifikan pada langkah kedua; dan (4) Melakukan uji serentak, uji parsial, dan pengujian asumsi $P H$ terhadap model Cox $P H$ final pada tingkat signifikansi $a=0,05$.

\section{HASIL DAN PEMBAHASAN}

\section{Karakteristik Sampel Penelitian}

Karakteristik data sampel penelitian dibagi menjadi dua bagian, karakteristik sampel untuk data kategorik dan karakteristik sampel untuk data numerik. Karakteristik sampel data kategorik dilihat melalui nilai jumlah dan persentase, sedangkan karakteristik sampel untuk data numerik dilihat melalui nilai minimum, maksimum, rata-rata, median dan standar deviasi. Karakteristik sampel penelitian untuk kedua bagian tersebut dapat dilihat pada Tabel 1 dan 2. 
Tabel 1. Karakteristik sampel penelitian variabel kategorik

\begin{tabular}{|c|c|c|c|}
\hline Variabel penjelas & Kategori & $n$ & $\%$ \\
\hline \multirow[t]{2}{*}{ Jenis kelamin $\left(\mathrm{X}_{1}\right)$} & 1: Perempuan & 38 & 76,00 \\
\hline & 2: Laki-laki & 12 & 24,00 \\
\hline \multirow[t]{2}{*}{ Pekerjaan $\left(\mathrm{X}_{2}\right)$} & 1: Perdagangan & 38 & 76,00 \\
\hline & 2: Pertanian & 12 & 24,00 \\
\hline \multirow[t]{5}{*}{ Kelompok umur (tahun) $\left(\mathrm{X}_{3}\right)$} & $1:<=30$ tahun & 2 & 4,00 \\
\hline & 2: $31-40$ tahun & 15 & 30,00 \\
\hline & 3: 41-50 tahun & 19 & 38,00 \\
\hline & 4: 51-60 tahun & 9 & 18,00 \\
\hline & 5: > 60 tahun & 5 & 10,00 \\
\hline \multirow[t]{2}{*}{ Penanggung jawab peminjaman $\left(\mathrm{X}_{5}\right)$} & 1: Individu & 31 & 62,00 \\
\hline & 2: Kelompok & 19 & 38,00 \\
\hline \multirow[t]{9}{*}{ Tempat domisili (X6) } & 1: Kuta Baro & 23 & 46,00 \\
\hline & 2: Baitussalam & 7 & 14,00 \\
\hline & 3: Leung Bata & 3 & 6,00 \\
\hline & 4: Syiah Kuala & 7 & 14,00 \\
\hline & 5: Kuta Raja & 1 & 2,00 \\
\hline & 6: Meuraxa & 2 & 4,00 \\
\hline & 7: Darussalam & 2 & 4,00 \\
\hline & 8: Ulee Kareng & 3 & 6,00 \\
\hline & 9: Kuta Alam & 2 & 4,00 \\
\hline
\end{tabular}

Jika dilihat berdasarkan variabel jenis kelamin dalam Tabel 1, diketahui bahwa mayoritas responden adalah berjenis kelamin perempuan, yaitu sebanyak 38 orang $(76,00 \%)$. Kemudian, sebanyak 38 orang mustahik $(76,00 \%)$ bekerja di sektor perdagangan. Selanjutnya jika dilihat berdasarkan kelompok umur, maka diketahui bahwa mayoritas responden berada pada kelompok umur 41-50 tahun, yaitu sejumlah 19 orang $(38,00 \%)$. Untuk variabel penanggung jawab peminjaman, mayoritas mustahik adalah bersifat pinjaman individual yaitu sebanyak 31 orang $(62,00 \%)$. Terakhir, untuk variabel penjelas tempat domisili, mayoritas responden berasal dari Kecamatan Kuta Baro yaitu sejumlah 23 orang mustahik (46,00\%), dan yang paling sedikit berasal dari Kecamatan Kuta Raja yaitu sejumlah 1 orang mustahik (2,00\%).

Tabel 2. Karakteristik sampel penelitian variabel numerik

\begin{tabular}{lccccc}
\hline \multicolumn{1}{c}{ Variabel penjelas } & Min & Mak & Rata-rata & Median & SD \\
\hline Lama waktu pembayaran angsuran (hari) $(\mathrm{T})$ & 7 & 68 & 39,86 & 34,50 & 13,18 \\
Jumlah biaya yang dipinjam (Juta) $\left(\mathrm{X}_{4}\right)$ & 2 & 10 & 6,08 & 6,00 & 1,99 \\
\hline
\end{tabular}

Karakteristik responden untuk data yang berskala numerik dapat dilihat melalui 5 nilai statistik, yaitu nilai minimum, maksimum, rata-rata, median dan standar deviasi. Berdasarkan tabel 2 diketahui bahwa nilai rata-rata lama waktu pembayaran angsuran pertama adalah sebesar 39,86 hari, dengan nilai standar deviasi sebesar 13,18 hari. Selanjutnya, nilai median dari lama waktu pembayaran angsuran tersebut adalah sebesar 34,50 hari. Nilai minimum dan maksimum lama waktu pembayaran angsuran pertama masing-masing adalah sebesar 7 dan 68 hari. Untuk variabel jumlah biaya yang dipinjam, nilai minimum dan maksimum pinjaman adalah sebesar 2 dan 10 juta rupiah. Sedangkan nilai median pinjamannya adalah sebesar 6 juta rupiah. Selanjutnya, jumlah rata-rata pinjaman yang dilakukan mustahik adalah sebesar 6,08 juta rupiah dengan standar deviasi sebesar 1,99 juta rupiah. 


\section{Model Cox proportional Hazard (Cox PH)}

Data durasi waktu mustahik dalam membayar angsuran mulai dari tanggal pencairan bantuan modal usaha sampai dengan pembayaran angsuran pada setiap bulan saat jatuh tempo merupakan data survival. Dalam hal ini, kejadian yang diamati adalah event pembayaran angsuran modal usaha program ZIS Produktif yang dilakukan oleh mustahik.

Model Cox $P H$ digunakan untuk melihat pengaruh variabel penjelas terhadap variabel respon berupa lama waktu terjadinya suatu kejadian. Variabel respon tersebut dapat didefinisikan sebagai kejadian tersensor dan kejadian tidak tersensor. Dalam penelitian ini, data tersensor adalah data lama waktu pembayaran angsuran pertama yang lebih dari 2 bulan ( $T>2$ bulan). Dengan demikian, apabila mustahik melakukan pembayaran angsuran pertama di bawah 2 bulan, maka data mustahik tersebut akan didefenisikan sebagai data yang tidak tersensor. Sedangkan mustahik yang melakukan pembayaran angsuran pertama yang lebih dari 2 bulan akan dikategorikan sebagai data yang tersensor. Data tersensor tersebut akan mempengaruhi pembentukan model Cox $P H$, sehingga penentuan batasan maksimal waktu pembayaran angsuran $(T)$ merupakan hal yang penting dalam penelitian ini. Tabel 3 menyajikan parameter model Cox $P H$ untuk basemodel yang memasukkan semua variabel penjelas di dalamnya.

Tabel 3. Model Cox PH untuk basemodel

\begin{tabular}{|c|c|c|c|}
\hline Variabel penjelas & Beta & Hazard rasio & p-value \\
\hline \multicolumn{4}{|l|}{ Jenis kelamin $\left(\mathrm{X}_{1}\right)$} \\
\hline 1 : Perempuan (R) & - & 1 & \\
\hline 2: Laki-laki & 0,819 & 2,269 & 0,123 \\
\hline \multicolumn{4}{|l|}{ Pekerjaan $\left(\mathrm{X}_{2}\right)$} \\
\hline 1: Perdagangan (R) & - & 1 & \\
\hline 2: Pertanian & 1,631 & 5,106 & 0,007 \\
\hline \multicolumn{4}{|l|}{ Kelompok umur (tahun) (X3) } \\
\hline $1:<=30(\mathrm{R})$ & - & 1 & \\
\hline $2: 31-40$ & 1,952 & 7,042 & 0,110 \\
\hline 3: $41-50$ & 1,455 & 4,286 & 0,221 \\
\hline 4: $51-60$ & 0,420 & 1,522 & 0,708 \\
\hline $5:>60$ & 2,812 & 16,642 & 0,054 \\
\hline Jumlah biaya yang dipinjam (Juta) $\left(\mathrm{X}_{4}\right)$ & 0,288 & 1,334 & 0,015 \\
\hline \multicolumn{4}{|l|}{ Penanggung jawab peminjam (X5) } \\
\hline 1: Individu (R) & - & 1 & \\
\hline 2: Kelompok & $-0,155$ & 0,857 & 0,762 \\
\hline \multicolumn{4}{|l|}{ Tempat domisili (X6) } \\
\hline 1: Kuta Baro (R) & 1 & 1 & \\
\hline 2: Baitussalam & 2,658 & 14,268 & $<0,001$ \\
\hline 3: Leung Bata & 1,118 & 3,060 & 0,187 \\
\hline 4: Syiah Kuala & 0,135 & 1,145 & 0,862 \\
\hline 5: Kuta Raja & 3,806 & 44,952 & 0,004 \\
\hline 6: Meuraxa & $-0,059$ & 0,943 & 0,955 \\
\hline 7: Darussalam & 2,004 & 7,415 & 0,035 \\
\hline 8: Ulee Kareng & $-0,923$ & 0,397 & 0,374 \\
\hline 9: Kuta Alam & 0,388 & 1,474 & 0,687 \\
\hline
\end{tabular}

(R): Reference Kategori; Likelihood Ratio test $=32,8 ; p$-value $=0,008$ 
Tabel 3 memuat nilai beta, hazard rasio dan p-value dari model Cox $P H$ untuk basemodel dengan semua variable penjelas di dalamnya. Terdapat 3 pengujian statistik terhadap model Cox $P H$ tersebut. Pertama, pengujian secara serentak melalui statistik Likelihood Ratio (LR) test. Kedua, pengujian secara parsial melalui statistik Wald, dan ketiga pengujian asumsi $P H$ melalui statistik Chi square. Untuk mendapatkan model final, perlu dilakukan proses seleksi variabel penjelas yang berpengaruh terhadap model Cox $P H$ secara bertahap. Pada tahap seleksi pertama, variabel penjelas dengan uji parsial Wald yang tidak signifikan pada $\mathrm{a}=0,1$ dari basemodel akan dikeluarkan dari model tersebut. Berdasarkan tabel 3, diketahui bahwa terdapat 4 buah variabel yang signifikan secara parsial pada tingkat signifikansi $\mathrm{a}=0,1$ yang ditandai oleh nilai $p$-value $<0,1$. Keempat variabel tersebut adalah pekerjaan mustahik, kelompok umur mustahik, jumlah biaya yang dipinjam, dan tempat domisili mustahik. Dengan demikian, terdapat 4 buah variabel yang signifikan pada seleksi tahap pertama untuk kelompok mustahik kategori lancar. Selanjutnya, uji serentak model melalui statistik $L R$ test menunjukkan bahwa model Cox $P H$ basemodel untuk mustahik kategori lancar adalah signifikan secara statistik yang ditunjukan oleh nilai $p$-value $<0,1$.

Selanjutnya, keempat variabel tersebut dimodelkan ulang untuk mendapatkan model Cox $P H$ final. Selain pengujian secara serentak dan parsial, model final juga perlu dilakukan pengujian asumsi Proportional Hazard $(P H)$. Asumsi $P H$ mensyaratkan bahwa nilai hazard rasio untuk variabel tersebut harus independen terhadap waktu. Sebuah variabel dinyatakan memenuhi asumsi $P H$ apabila memiliki nilai statistik Chi-square yang tidak signifikan pada a $=0,05$. Tabel 4 merangkum nilai statistik Chi-square dan $p$-value dari pengujian asumsi $P H$ tersebut. Berdasarkan tabel 4, terlihat bahwa keempat variabel pada model Cox $P H$ final untuk mustahik kategori lancar memiliki nilai Chi-square yang tidak signifikan yang ditandai dengan nilai $p$ value $>0,05$. Dengan demikian, keempat variabel tersebut dinyatakan telah memenuhi asumsi $\mathrm{PH}$.

Tabel 4. Asumsi Proportional Hazard $(P H)$ model final

\begin{tabular}{|c|c|c|}
\hline Variabel penjelas & Chi-square & p-value \\
\hline \multicolumn{3}{|l|}{ Pekerjaan $\left(\mathrm{X}_{2}\right)$} \\
\hline 1: Perdagangan (R) & - & - \\
\hline 2: Pertanian & 2,477 & 0,116 \\
\hline \multicolumn{3}{|l|}{ Kelompok umur (tahun) (X3) } \\
\hline $1:<=30(\mathrm{R})$ & - & - \\
\hline $2: 31-40$ & 2,104 & 0,147 \\
\hline 3: $41-50$ & 1,846 & 0,174 \\
\hline 4: $51-60$ & 2,619 & 0,106 \\
\hline $5:>60$ & 0,542 & 0,462 \\
\hline Jumlah biaya yang dipinjam (juta) $\left(\mathrm{X}_{4}\right)$ & 0,455 & 0,500 \\
\hline \multicolumn{3}{|l|}{ Tempat domisili $\left(\mathrm{X}_{6}\right)$} \\
\hline 1: Kuta Baro & - & - \\
\hline 2: Baitussalam & 1,106 & 0,293 \\
\hline 3: Leung Bata & 0,002 & 0,965 \\
\hline 4: Syiah Kuala & 0,879 & 0,349 \\
\hline 5: Kuta Raja & 0,539 & 0,463 \\
\hline 6: Meuraxa & 0,212 & 0,645 \\
\hline 7: Darussalam & 0,223 & 0,637 \\
\hline 8: Ulee Kareng & 0,448 & 0,503 \\
\hline 9: Kuta Alam & 3,455 & 0,063 \\
\hline
\end{tabular}

(R): Reference Kategori 
Model Cox $P H$ final untuk kelompok mustahik kategori lancar ditampilkan pada tabel 5, dan dapat ditulis dalam persamaan matematis sebagai berikut:

$$
\begin{aligned}
h(t, \boldsymbol{X})=h_{0}(t) \exp & \left(1,338 X_{2(2)}+1,582 X_{3(2)}+1,334 X_{3(3)}+0,462 X_{3(4)}+2,655 X_{3(5)}+0,286 X_{4}+2,863 X_{6(2)}\right. \\
& +0,917 X_{6(3)}+0,123 X_{6(4)}+3,631 X_{6(5)}-0,237 X_{6(6)}+2,410 X_{6(7)}-0,182 X_{6(8)} \\
& \left.+0,258 X_{6(9)}\right)
\end{aligned}
$$

\begin{tabular}{|c|c|c|c|c|}
\hline Variabel penjelas & Beta & Hazard rasio & Wald & p-value \\
\hline \multicolumn{5}{|l|}{ Pekerjaan $\left(\mathrm{X}_{2}\right)$} \\
\hline 1: Perdagangan (R) & - & 1 & & \\
\hline 2: Pertanian & 1,338 & 3,811 & 2,540 & 0,011 \\
\hline \multicolumn{5}{|l|}{ Kelompok umur (tahun) $\left(\mathrm{X}_{3}\right)$} \\
\hline $1:<=30(\mathrm{R})$ & - & 1 & & \\
\hline $2: 31-40$ & 1,582 & 4,865 & 1,450 & 0,147 \\
\hline 3: $41-50$ & 1,334 & 3,797 & 1,230 & 0,220 \\
\hline 4: $51-60$ & 0,462 & 1,587 & 0,420 & 0,677 \\
\hline $5:>60$ & 2,655 & 14,227 & 2,030 & 0,043 \\
\hline Jumlah biaya yang dipinjam (Juta) $\left(\mathrm{X}_{4}\right)$ & 0,286 & 1,332 & 2,460 & 0,014 \\
\hline \multicolumn{5}{|l|}{ Tempat domisili $\left(\mathrm{X}_{6}\right)$} \\
\hline 1: Kuta Baro (R) & - & 1 & & \\
\hline 2: Baitussalam & 2,863 & 17,512 & 3,920 & $<0,001$ \\
\hline 3: Leung Bata & 0,917 & 2,502 & 1,280 & 0,201 \\
\hline 4: Syiah Kuala & 0,123 & 1,131 & 0,190 & 0,846 \\
\hline 5: Kuta Raja & 3,631 & 37,735 & 2,960 & 0,003 \\
\hline 6: Meuraxa & $-0,237$ & 0,789 & $-0,260$ & 0,794 \\
\hline 7: Darussalam & 2,410 & 11,132 & 2,790 & 0,005 \\
\hline 8: Ulee Kareng & $-0,182$ & 0,834 & $-0,230$ & 0,820 \\
\hline 9: Kuta Alam & 0,258 & 1,294 & 0,290 & 0,771 \\
\hline
\end{tabular}

Tabel 5. Model Cox $P H$ final kelompok mustahik kategori lancar

(R): Reference Kategori; Likelihood Ratio test $=30,2 ;$-value $=0,007$

Model Cox $P H$ final tersebut terdiri atas 4 buah variabel penjelas dengan uji serentak melalui statistik $L R$ test yang signifikan pada a = 0,05. Nilai $L R$ test adalah sebesar 30,2 dengan $p$-value sebesar 0,007. Keempat variabel tersebut juga signifikan secara parsial yang ditandai oleh adanya beberapa nilai p-value < 0,05 dari statistik Wald untuk masing-masing variabel penjelasnya. Dengan demikian, model Cox $P H$ final tersebut telah memenuhi ketiga uji yang telah dilakukan. Berdasarkan model Cox $P H$ final yang terdapat dalam tabel 5, dapat dilakukan interpretasi sebagai berikut: (1) Pembayaran angsuran pertama bantuan modal usaha program ZIS Produktif Baitul Mal Aceh untuk mustahik yang bekerja di sektor pertanian cenderung 3,81 kali lebih cepat dilakukan dibandingkan dengan mustahik yang bekerja di sektor perdagangan sebagai reference kategori; (2) Pembayaran angsuran pertama bantuan modal usaha program ZIS Produktif Baitul Mal Aceh untuk mustahik yang berumur > 60 tahun cenderung 14,23 kali lebih cepat dilakukan dibandingkan dengan mustahik yang berumur $<=30$ tahun sebagai reference kategori; (3) Untuk setiap selisih pinjaman modal usaha program ZIS Produktif Baitul Mal Aceh sebesar 1 juta rupiah, maka kelajuan mustahik untuk membayar angsuran menjadi 1,33 kali lebih besar. Sebagai ilustrasi, mustahik yang melakukan pinjaman dengan jumlah 6 juta rupiah cenderung 1,33 kali lebih cepat 
membayarkan angsurannya dibandingkan dengan mustahik yang meminjam modal usaha dengan jumlah 5 juta rupiah. Demikian pula untuk pinjaman antara 3 juta dan 4 juta rupiah. Mustahik dengan jumlah pinjam 4 juta rupiah cenderung 1,33 kali lebih cepat membayar angsurannya dari pada mustahik yang melakukan pinjaman sebesar 3 juta rupiah; (4) Dibandingkan dengan mustahik yang tinggal di wilayah Kecamatan Kuta Baro sebagai reference kategori, mustahik yang tinggal di wilayah Kecamatan Baitussalam, Kecamatan Kuta Raja, dan Kecamatan Darussalam masing-masing memiliki kecenderungan 17,51 kali, 37,74 kali, dan 11,13 kali lebih cepat dalam membayarkan angsuran pertamanya kepada Baitul Mal Aceh.

\section{KESIMPULAN}

Penelitian ini dilakukan khusus pada kelompok mustahik kategori lancar penerima bantuan modal usaha program ZIS Produktif Baitul Mal Aceh dengan batas lama waktu pembayaran angsuran pertama yang dipertimbangkan $(T)$ tidak lebih dari 2 bulan. Dari 6 buah variabel penjelas yang diteliti dalam penelitian ini, 4 diantaranya memiliki pengaruh yang signifikan terhadap variabel respon lama waktu pembayaran angsuran pertama modal usaha tersebut berdasarkan model Cox Proportional Hazard $(P H)$ pada tingkat signifikansi 5\%. Keempat variabel tersebut adalah pekerjaan mustahik, kelompok umur mustahik, jumlah biaya yang dipinjam, dan tempat domisi mustahik.

\section{DAFTAR PUSTAKA}

Al-quran al-hadi. (2017). Perintah dan Pelaksanaan Zakat yang Digandengkan dengan Shalat. (http:/ / alquranalhadi.com/kajian/tema/1061/perintah-dan-pelaksanaan-zakat-yangdigandengkan-dengan-shalat) diunduh pada 9 Juli 2017.

Baitul Mal Aceh (2015). "Kebijakan Manajemen Unit ZIS Produktif Baitul Mal Aceh", Banda Aceh: Baitul Mal Aceh.

Baitul Mal Aceh (2017). Pemberdayaan Ekonomi. (http://baitulmal.acehprov.go.id/?page_id=2259) diunduh pada 20 Mei 2017.

BPS Aceh (2014). “Aceh Dalam Angka 2014”, Banda Aceh: BPS Provinsi Aceh, p.112.

Jim, U. (2017). "Modul Training Tauhid”, Banda Aceh: Dayah Liqaurrahmah, p. 15.

Kleinbaum, D.G., dan Klein, M. (2005). "Survival Analysis”, Edisi Kedua, New York: Springer Science Business Media, Inc.

Kleinbaum, D., G., dan Klein, M. (2011). "Survival Analysis: A Self-Learning Text", Edisi Kedua, New York: Springer, pp. 94-100.

Machin, D., Cheung, Y.B. dan Parmar, M.K.B. (2006). "Survival Analysis: A Practical Approach", Edisi Kedua, London: John Wiley \& Sons Ltd., pp. 94-124.

Zacks, S. (1991). "Introduction to Reliability Analysis Probability Models and Statistical Methods", New York: Springer text in Statistics. 